\title{
Highly efficient silica sink in monomictic Lake Biwa in Japan
}

\author{
Naoshige Goto ${ }^{1 *}$, Hisayuki Azumi ${ }^{1}$, Tetsuji Akatsuka ${ }^{1}$, Masaki Kihira ${ }^{2}$, Masakazu Ishikawa ${ }^{1}$, \\ Kaori Anbutsu ${ }^{3}$ and Osamu Mitamura ${ }^{1}$ \\ ${ }^{1}$ School of Environmental Science, The University of Shiga Prefecture, 2500 Hassaka-cho, Hikone, Shiga 522-8533, Japan \\ 2 Iga Community-Based Research Institute, Mie University, 1-3-3 Yumegaoka, Iga, Mie 518-0131, Japan \\ ${ }^{3}$ Fisheries and Environmental Oceanography, Graduate School of Agriculture, Kyoto University, Kitashirakawa, Sakyo-ku, \\ Kyoto 606-8502, Japan
}

Received 25 June 2012; Accepted 6 April 2013

\begin{abstract}
In order to clarify the mechanisms underlying high efficiency of the silica sink in monomictic Lake Biwa in Japan, vertical flux of biogenic silica (BSi) was measured using sediment traps over a period of 15 months. The sediment traps were deployed at depths of 30 and $70 \mathrm{~m}$. On a global scale, BSi fluxes in Lake Biwa were very high, ranging from 20 to $1087 \mathrm{mg} \mathrm{Si} . \mathrm{m}^{-2} \cdot \mathrm{d}^{-1}$ at the $30 \mathrm{~m}$ trap and $12-999 \mathrm{mg} \mathrm{Si} \cdot \mathrm{m}^{-2} \cdot \mathrm{d}^{-1}$ at the $70 \mathrm{~m}$ trap throughout the observation period. The BSi fluxes at both traps increased significantly during the winter period and the ratio of BSi fluxes in the winter period to annual BSi fluxes ranged from 27 to $62 \%$. In the winter period, when nutrients are supplied from the hypolimnion to the epilimnion, the distribution of photosynthetically active diatoms was almost homogeneous in all layers, including the aphotic layer. At this time, the diatoms assimilated dissolved silica (DSi) in a wider layer containing a part of aphotic layer in order to produce rigid frustules, which accumulated rapidly in bottom sediments as DSi concentration in the water column decreased. Thus, size of the silica sink in Lake Biwa is enhanced during the winter holomictic mixing period through interaction between physical (thermocline disruption: transfer of diatoms to deep layers by vertical convection), chemical (nutrient supply from deep layers) and biological (dominance of active diatoms in all layers) processes.
\end{abstract}

Key words: Silica sink / biogenic silica (BSi) / diatom / vertical flux / Lake Biwa

\section{Introduction}

Recent studies have reported that absolute loads supply of dissolved silica (DSi: $\mathrm{Si}(\mathrm{OH})_{4}$ ) from terrestrial to marine environments has decreased due to increase in nutrient loads [dissolved inorganic nitrogen (DIN: sum of ammonia, nitrite and nitrate) and dissolved inorganic phosphate (DIP)] and stagnation in limnetic systems (Humborg et al., 1997, 2006; Nixon, 2003; Sferratore et al., 2008). Decrease in the supply of DSi has led to a change in relative loads to coastal areas (i.e., decrease in DSi: DIN and DSi: DIP) (Garnier et al., 2010). These disruptions to the biogeochemical environment may cause changes in the structure of phytoplankton communities, such as those of diatoms and non-siliceous algae, greatly affecting marine ecosystems (Humborg et al., 1997, 2000; Teubner and Dokulil, 2002). This sequence of phenomena is referred to as the silica deficiency hypothesis (Schelske and Stoermer, 1971, 1972) and is regarded as a critical

\footnotetext{
*Corresponding author: gotonao@ses.usp.ac.jp
}

factor in aquatic marine systems (Billen et al., 1991; Conley et al., 1993; Turner et al., 2003; Gong et al., 2006). Interestingly, compared to nitrogen and phosphorus, relatively few studies have examined silica dynamics of limnetic systems. It is very important that we undertake studies focused on understanding the mechanisms by which silica sinks operate in limnetic systems, as doing so will allow managers to address silica deficiency problems, including their impact on land-ocean systems.

The area examined in this study, Lake Biwa, is a well-known silica sink (Hori et al., 1969; Miyajima et al., 1995; Goto et al., 2007). In a previous study, we reported that the sedimentation rate of silica in Lake Biwa was $2.0 \times 10^{7} \mathrm{~kg} \mathrm{Si} . \mathrm{y}^{-1}$, which is equivalent to approximately $80 \%$ of annual flow discharge of DSi into Lake Biwa (Goto et al., 2007). Although the volume of Lake Biwa $\left(2.75 \times 10^{10} \mathrm{~m}^{3}\right)$ is very small compared to that of Lake Michigan $\left(487 \times 10^{10} \mathrm{~m}^{3}\right)$ and Lake Erie $\left(45.8 \times 10^{10} \mathrm{~m}^{3}\right)$, the size of the silica sink in Lake Biwa is approximately a quarter of that in each Great Lake. We also clarified how the silica sink in Lake Biwa is enhanced during the winter 
period (December to February) as holomictic mixing transports nutrients, particularly DIP, from the deeper layers to the surface layers for assimilation of DSi by large centric diatoms and subsequent descent of their frustules to bottom sediments (Goto et al., 2007). However, in that study, while the size and mechanisms associated with the silica sink in Lake Biwa were estimated on the basis of seasonal variations in DSi concentrations in the lake and its watershed, downward flux of biogenic silica (BSi, diatom frustules) was not directly measured. As a consequence, seasonal variation in the amount of $\mathrm{Si}$ exported to the lake bottom through diatom sinking was not clearly defined or quantitatively characterized. Despite an increasing awareness of the importance of BSi dynamics in limnetic systems, relatively few studies have been conducted on vertical flux of BSi in freshwater lakes (Schelske et al., 1984; Bootsma et al., 2003; Pilskaln, 2004; Müller et al., 2005).

This study, therefore, examined the vertical flux of BSi and total particulate silica (TPSi) in the northern basin of monomictic Lake Biwa using cylindrical sediment traps over a period of 15 months. In addition, physicochemical and biological parameters (water temperature, concentrations of nutrients, particulate organic matter, chlorophyll $a(\mathrm{Chl} a)$ and potential maximum quantum yield $\left[F_{\mathrm{v}} / F_{\mathrm{m}}\right]$ of phytoplankton) were also measured. These observations were then used for further clarification of detailed mechanisms associated with the silica sink in Lake Biwa.

\section{Materials and methods}

\section{Sampling}

The vertical fluxes of particulate matters [BSi, TPSi and particulate organic carbon (POC), particulate organic nitrogen (PON) and particulate phosphorus (PP)] were measured using cylindrical sediment traps (three cups, mouth diam.: $70 \mathrm{~mm}$ and length: $640 \mathrm{~mm}$ ). The sediment traps were deployed at Sta. T1 (30 and $70 \mathrm{~m}$ depth) in the northern basin of Lake Biwa (surface area: $670 \mathrm{~km}^{2}$, mean water depth: $43 \mathrm{~m}$, maximum depth: $104 \mathrm{~m}$ ), Japan, for a period of 1-14 days a month from December 2004 to February 2006 (Fig. 1). During sampling, a 1-mm mesh was placed over the mouth of the trap to prevent large swimmers from entering the traps.

At the time of trap deployment, water column samples were collected along a vertical distribution $(0-85 \mathrm{~m}$ : 15 layers) to measure DSi, other nutrients (DIN and DIP), Chl $a$, particulate matter (BSi, POC, PON and PP) and $F_{\mathrm{v}} / F_{\mathrm{m}}$ of phytoplankton at Sta. T1 using a Van Dorn water sampler. Water temperature and underwater irradiance were measured using a CTD (ACL-220, Alec) fitted with a PAR sensor (Li-193, LiCor).

\section{Analytical methods}

After recovery of the traps, sediment trap samples for measurement of BSi and TPSi were immediately filtered

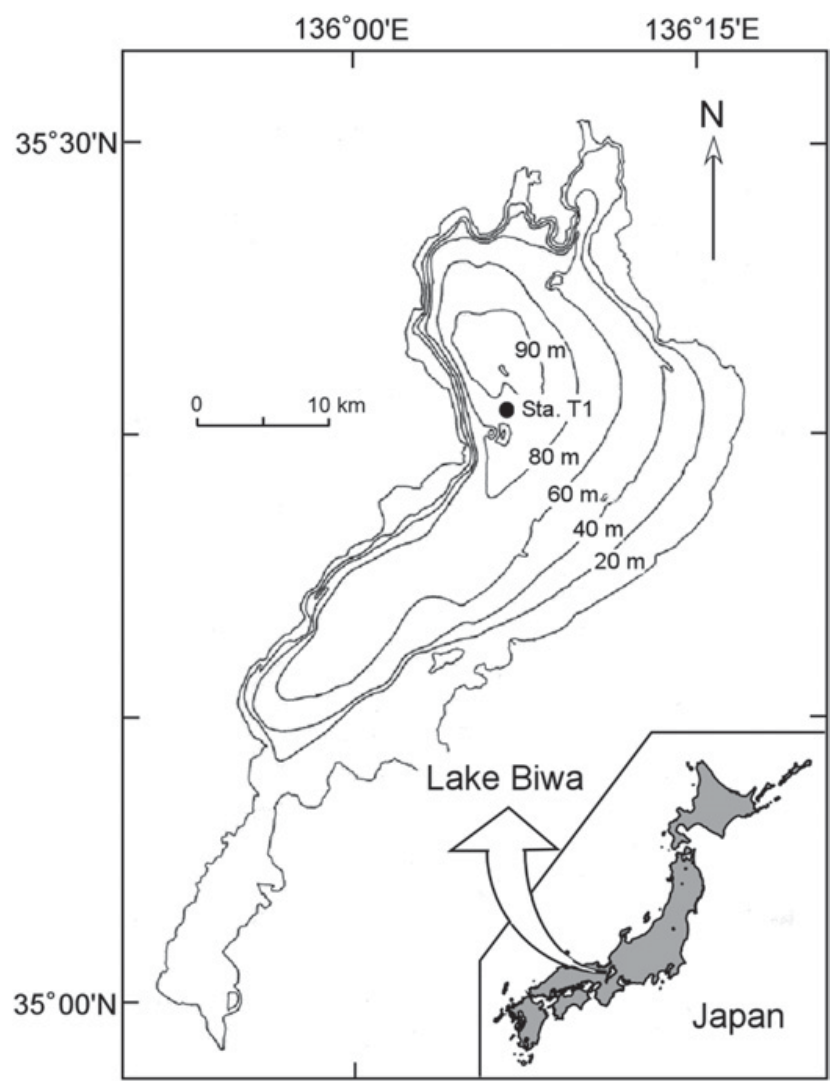

Fig. 1. Map of Lake Biwa in Japan showing the location of sampling Station T1 (solid circle).

through polycarbonate filters (pore size: $0.6 \mu \mathrm{m}$, Nuclepore), which were then dried at $60^{\circ} \mathrm{C}$ for $48 \mathrm{~h}$ and stored in a desiccator at room temperature until analysis. To determine POC, PON and PP, the remaining samples were immediately filtered through glass fiber filters $(\mathrm{GF} / \mathrm{F}$, Whatman) that had been precombusted at $420^{\circ} \mathrm{C}$ before storing at $-30{ }^{\circ} \mathrm{C}$ in a deep freezer until chemical analysis. In addition, subsamples (1 Liter) were preserved in buffered formalin solution (final concentration 5\%) to determine algal species composition.

BSi concentration was measured using the method of DeMaster (1981) with slight modifications. Briefly, BSi concentration was determined based on difference in dissolution rates between $\mathrm{BSi}$ and lithogenic silica (LSi) in an alkaline solution $\left(1 \% \mathrm{Na}_{2} \mathrm{CO}_{3}, 85^{\circ} \mathrm{C}\right)$. DSi in the solution was measured using the molybdenum blue or yellow method of Mullin and Riley (1955). The analytical precision of $\mathrm{BSi}$, expressed as standard deviation, was $0.5 \mu \mathrm{mol} . \mathrm{L}^{-1}$.

Filter sample for measurement of TPSi was digested by heating in an alkaline solution $\left(0.5 \% \mathrm{Na}_{2} \mathrm{CO}_{3}\right)$, and the solution was evaporated to dryness (Fujinaga and Hori, 1982; Kawamura and Goto, 1994). The dried residue was fused with a burner. After cooling, the dried residue was dissolved by heating in distilled water. The supernatant was neutralized by $\mathrm{HCl}$ and $\mathrm{DSi}$ in the supernatant was measured using the molybdenum blue or yellow method of Mullin and Riley (1955). 


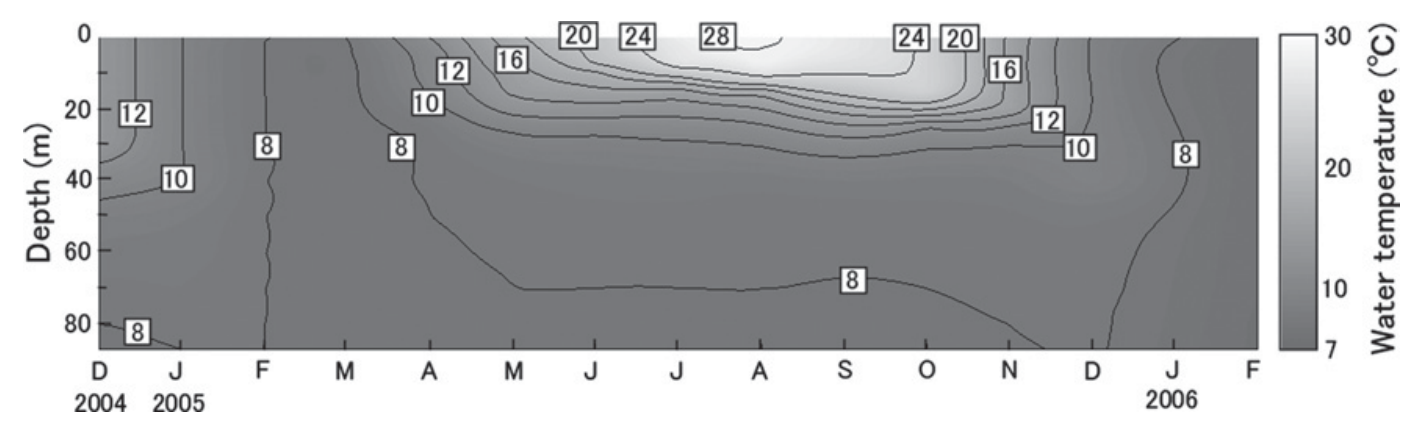

Fig. 2. Vertical distribution of water temperature at Station T1 in Lake Biwa from December 2004 to February 2006.

LSi concentrations were calculated by subtracting BSi concentration from TPSi concentration.

POC and PON were analysed with a $\mathrm{CHN}$ corder (MT-5, Yanaco). PP was determined by the method of Menzel and Corwin (1965).

Water samples collected for chemical analysis of DSi were immediately filtered through polycarbonate filters (pore size: $0.6 \mu \mathrm{m}$, Nuclepore). Water samples collected for chemical analysis of other nutrients and $\mathrm{Chl} a$ were immediately filtered through glass fiber filters (Whatman, $\mathrm{GF} / \mathrm{F}$ ) that had been precombusted at $450{ }^{\circ} \mathrm{C}$. Filtrates for determination of DSi and other nutrients were stored at $4{ }^{\circ} \mathrm{C}$ and $-30{ }^{\circ} \mathrm{C}$, respectively, while filters for determination of $\mathrm{Chl} a$ were stored at $-80^{\circ} \mathrm{C}$ until chemical analysis in the laboratory. Water samples for determination of algal species composition were preserved in a buffered formalin solution (final concentration 5\%).

DSi concentrations of water from the water column were analyzed spectrophotometrically using the molybdenum blue or yellow method of Mullin and Riley (1955). Ammonia concentration was determined by the method of Sagi (1966), nitrite concentration after Bendschneider and Robinson (1952) and phosphate concentration after Murphy and Riley (1962). Nitrate was analyzed using an ion chromatographic analyzer (DX-120, Dionex). Chl $a$ concentration was analyzed fluorometrically (10-AU, Turner Design) after extraction in 90\% acetone and ultrasonication for $30 \mathrm{~s}$ (Holm-Hansen et al., 1965).

The parameter $F_{\mathrm{v}} / F_{\mathrm{m}}$, which is an indicator of maximum photochemical efficiency of PSII reaction centers in dark-adapted algal cells, was measured using a Water-PAM chlorophyll fluorometer (Heinz Walz $\mathrm{GmbH}$ ) equipped with a Water-ED Emitter-Detector Unit (Heinz Walz GmbH). Samples were placed in a 15-mm diameter quartz cuvette after 20-30 min of darkadaptation (Schreiber et al., 1995).

\section{Results}

\section{Physicochemical and biological parameters in the water column}

Lake Biwa was characterized as a monomictic lake based on its circulation period (February) and stratification period (April to November) (Fig. 2). While the water temperature during circulation period at Sta. T1 was almost uniform in all layers, three separate layers could be distinguished during the stratification period: epilimnion (0-20 m: $17.4 \pm 6.0^{\circ} \mathrm{C}$, mean $\pm \mathrm{SD}$ ), thermocline and hypolimnion $\left(30-87 \mathrm{~m}: 8.3 \pm 0.6^{\circ} \mathrm{C}\right)$. Euphotic zone depth (depth of $1 \%$ relative irradiance) at Sta. T1 ranged from $15.2 \mathrm{~m}$ (November 2005) to $29.2 \mathrm{~m}$ (March 2005) throughout the study period.

The concentration of DSi at Sta. T1 varied from 5.1 to 78.6 $\mu \mathrm{mol} . \mathrm{L}^{-1}\left(24.1 \pm 13.5 \mu \mathrm{mol} . \mathrm{L}^{-1}\right)$ throughout the study period (Fig. 3). During the stratification period, DSi concentration in the epilimnion (range: 5.2-24.5 $\mu$ mol. $\left.\mathrm{L}^{-1}, \quad 14.8 \pm 6.1 \mu \mathrm{mol} . \mathrm{L}^{-1}\right)$ was markedly lower than that in hypolimnion (range: 23.7-78.6 $\mu \mathrm{mol} . \mathrm{L}^{-1}$, $34.5 \pm 12.4 \mu \mathrm{mol} . \mathrm{L}^{-1}$ ), increasing gradually below the thermocline with an increase in water depth. Conversely, DSi concentration in the circulation period $(22.9 \pm 0.7$ $\mu$ mol. $\mathrm{L}^{-1}$ ) was distributed almost uniformly in all layers. The standing stock of DSi in the water column $\left(\mathrm{mol} . \mathrm{m}^{-2}\right)$ at Sta. T1 varied from 1.77 to $2.68 \mathrm{~mol} . \mathrm{m}^{-2}$ during the entire observation period, and the standing stock in the circulation period (February 2005 and 2006) tended to decrease markedly compared to the other months (Fig. 3). The concentrations of DIN and DIP at Sta. T1 ranged from 0.4 to $26.4 \mu \mathrm{mol} . \mathrm{L}^{-1}\left(13.9 \pm 5.7 \mu \mathrm{mol} . \mathrm{L}^{-1}\right)$ and from 0.01 to $0.30 \mu \mathrm{mol} . \mathrm{L}^{-1}\left(0.05 \pm 0.05 \mu \mathrm{mol} . \mathrm{L}^{-1}\right)$ during the observation period, respectively. The mean DSi: DIP and DIN: DIP molar ratios were 872 (range: 128-5750) and 577 (range: 44-2850), respectively.

The molar ratio of BSi to PP (BSi: PP) at depths of $30 \mathrm{~m}$ and $70 \mathrm{~m}$ in the water column ranged from 5.2 to 74.9 $(30.3 \pm 21.2)$ and 8.8 to $36.4(21.4 \pm 8.2)$ throughout the observation period, respectively (Fig. 4). The BSi: PP ratio exhibited a tendency to increase in the winter period and were almost equal at both depths during the circulation period (February 2005 and 2006). The molar ratio of PON: PP at depths of 30 and $70 \mathrm{~m}$ ranged from 7.8 to 31.3 $(20.6 \pm 5.2)$ and from 9.0 to $22.6(16.1 \pm 3.7)$, respectively (Fig. 4).

The concentration of Chl $a$ at Sta. T1 ranged from 0.07 to $11.7 \mu \mathrm{g}$ chl $a . \mathrm{L}^{-1}$ during the observation period, with two marked peaks observed in the epilimnion in December 2004 and November 2005 (Fig. 5A). During the circulation period, Chl a concentration remained approximately uniform in all layers (February 2005: $1.87 \pm 0.11 \mu \mathrm{g}$ chl $a . \mathrm{L}^{-1}$, February $2006: 1.87 \pm 0.22 \mu \mathrm{g}$ 


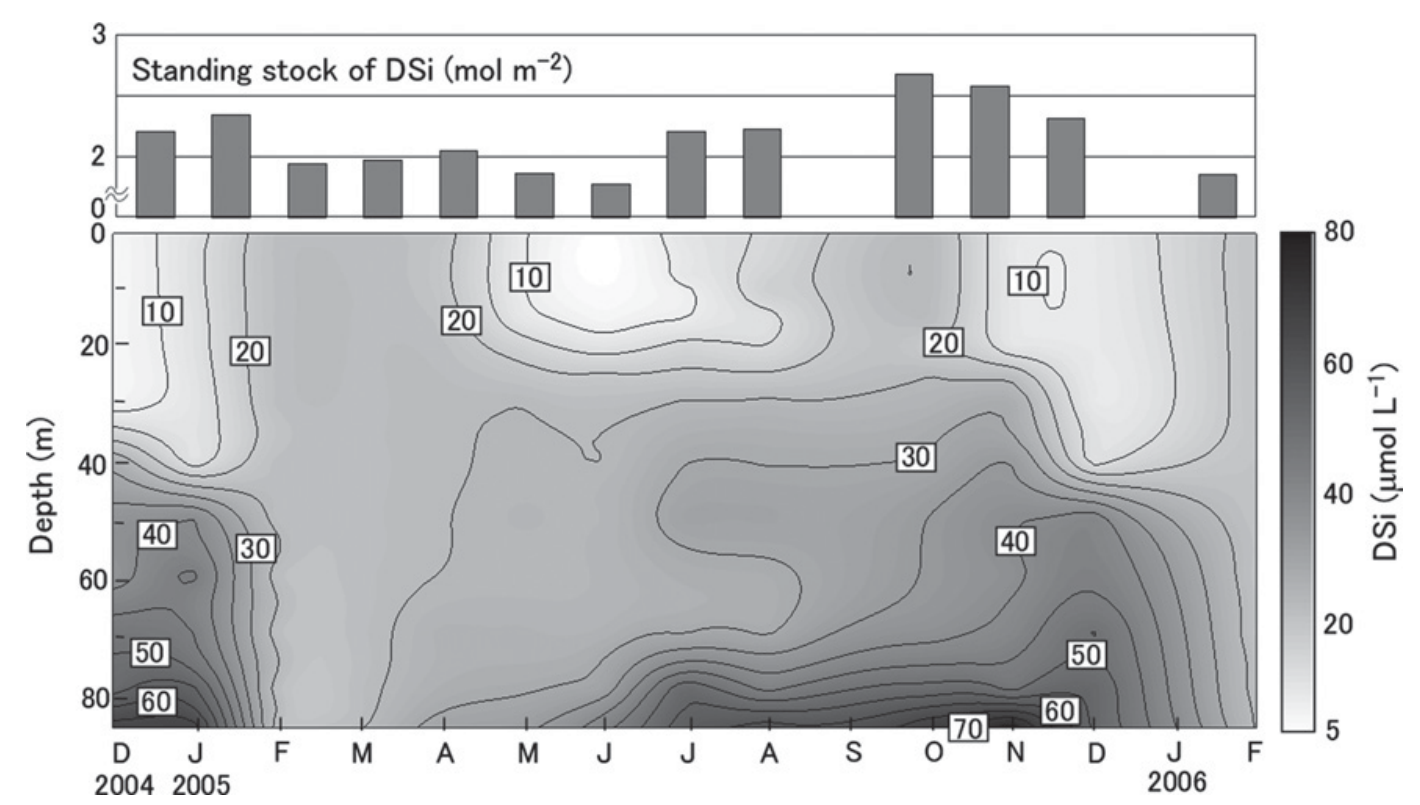

Fig. 3. Vertical distribution of DSi concentration and the standing stock of DSi at Station T1 in Lake Biwa from December 2004 to February 2006.

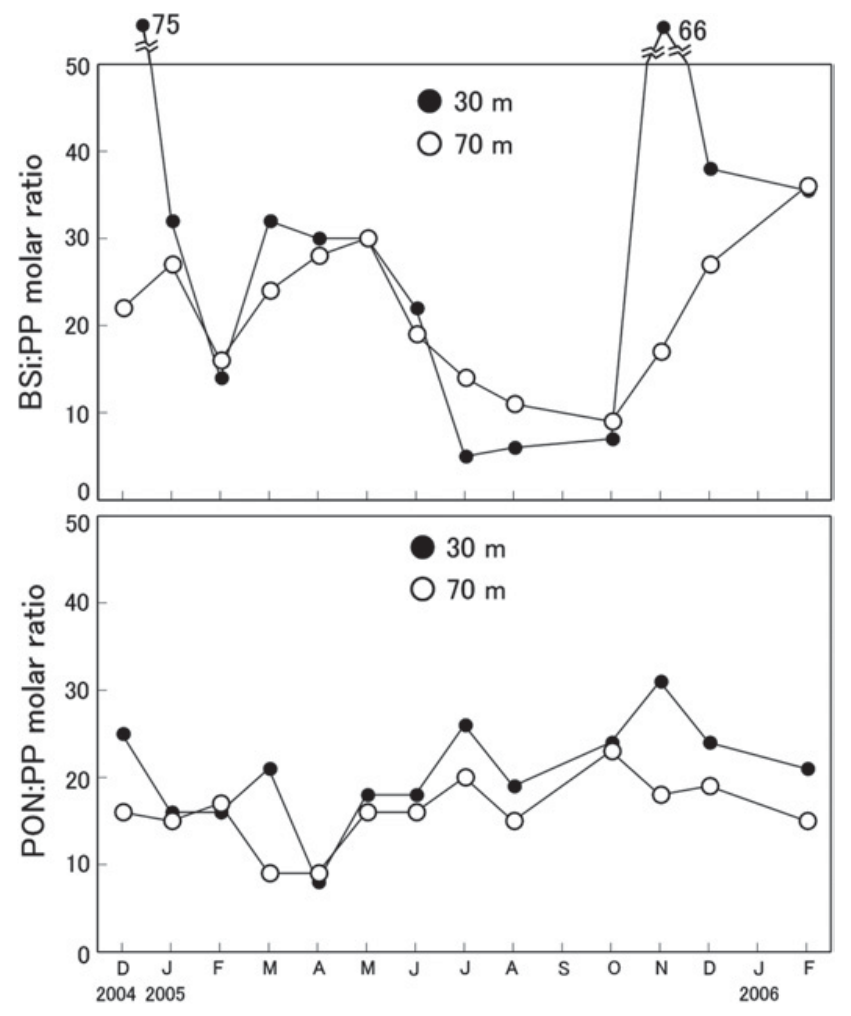

Fig. 4. Molar ratio of $\mathrm{BSi}$ and $\mathrm{PON}$ to particulate phosphorus (PP) at depths of $30 \mathrm{~m}$ and $70 \mathrm{~m}$ in the water column at Station T1 in Lake Biwa from December 2004 to February 2006.

chl $\left.a . \mathrm{L}^{-1}\right)$. On the other hand, during the stratification period, Chl a concentration was relatively high in the epilimnion $\left(4.16 \pm 2.26 \mu \mathrm{g}\right.$ chl $\left.a . \mathrm{L}^{-1}\right)$, decreasing markedly below the thermocline (hypolimnion: $0.82 \pm 1.09 \mu \mathrm{g}$ chl $\left.a . \mathrm{L}^{-1}\right)$.
The $F_{\mathrm{v}} / F_{\mathrm{m}}$ value at Sta. T1 ranged from 0.07 to 0.76 and exhibited a tendency to increase during the circulation period and decrease during the stratification period (Fig. 5B). During the circulation period, $F_{\mathrm{v}} / F_{\mathrm{m}}$ values were similar in all layers (February 2005: $0.67 \pm 0.03$; February 2006: $0.65 \pm 0.01)$. However, during the stratification period, $F_{\mathrm{v}} / F_{\mathrm{m}}$ values in the epilimnion ranged from 0.30 to $0.75(0.62 \pm 0.08)$, and below the thermocline, these values decreased markedly with water depth. During the stratification period, $F_{\mathrm{v}} / F_{\mathrm{m}}$ values in the hypolimnion ranged from 0.07 to $0.71(0.41 \pm 0.19)$.

\section{Particle fluxes from sediment traps}

BSi fluxes in traps at 30 and $70 \mathrm{~m}$ at Sta. T1 ranged from 20 to $1087 \mathrm{mg} \mathrm{Si} \cdot \mathrm{m}^{-2} \cdot \mathrm{d}^{-1} \quad(392 \pm 319 \mathrm{mg}$ Si.m $\left.{ }^{-2} \cdot \mathrm{d}^{-1}\right)$ and from 12 to $999 \mathrm{mg} \mathrm{Si} \cdot \mathrm{m}^{-2} \cdot \mathrm{d}^{-1}$ $\left(313 \pm 319 \mathrm{mg} \mathrm{Si} \cdot \mathrm{m}^{-2} \cdot \mathrm{d}^{-1}\right)$ throughout the observation period, respectively (Fig. 6). BSi fluxes in the upper and lower traps showed a tendency to increase during the winter period, and to decrease in the summer stratification period. While the $\mathrm{BSi}$ fluxes in the upper trap were higher than those in the lower trap during the first winter period (December 2004 to February 2005), BSi fluxes in the upper trap were lower than those in the lower trap during the second winter period (December 2005 and February 2006). This may be attributed to an episodic lateral transport of resuspended sediment from a steep slope on the west side of the lake basin.

The ratio of BSi fluxes to TPSi fluxes in 30 and $70 \mathrm{~m}$ traps ranged from 12 to $82 \%(56 \pm 21 \%)$ and from 15 to $76 \%(50 \pm 17 \%)$, respectively (Fig. 7$)$. The BSi: TPSi flux in both traps showed a decreasing tendency in summer when thermal stratification develops and water 


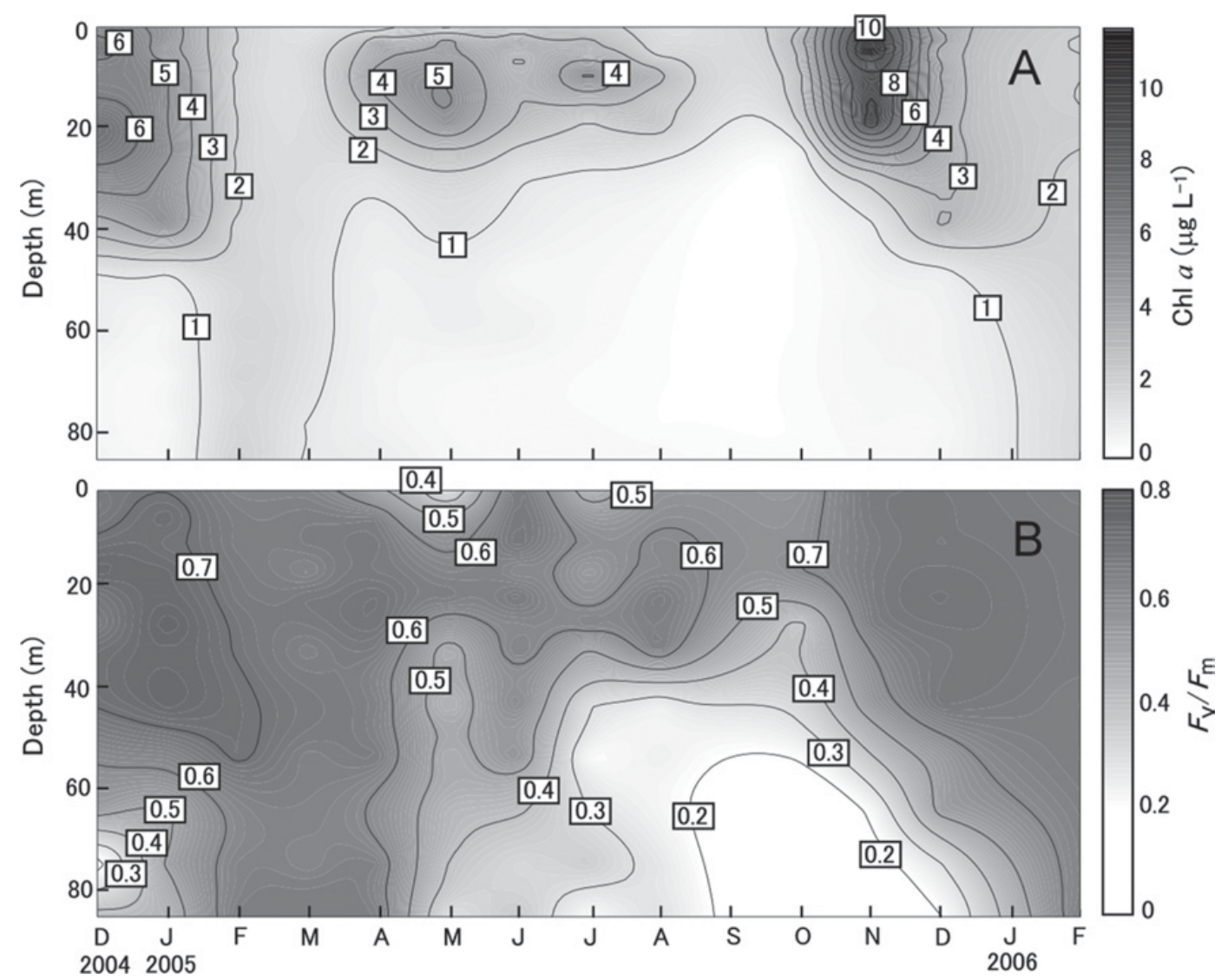

Fig. 5. A: Vertical distribution of Chl $a$ concentration at Station T1 in Lake Biwa from December 2004 to February 2006 . B: Vertical distribution of potential maximum quantum yield $\left(F_{\mathrm{v}} / F_{\mathrm{m}}\right)$ of phytoplankton at Station T1 in Lake Biwa from December 2004 to February 2006.

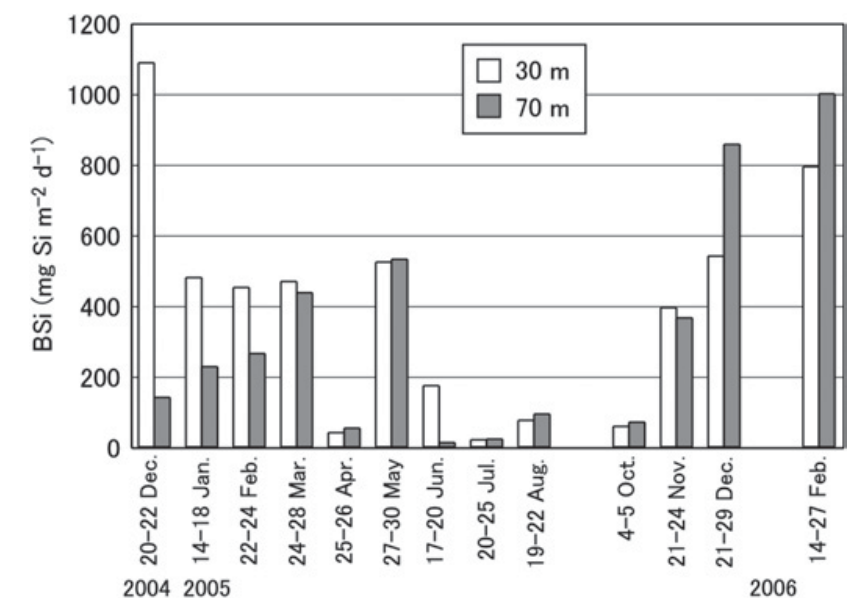

Fig. 6. BSi fluxes in upper trap $(30 \mathrm{~m})$ and lower trap $(70 \mathrm{~m})$ at Station T1 in Lake Biwa from December 2004 to February 2006.

temperature increases, i.e., the ratio of LSi fluxes to TPSi fluxes decreased in the winter period and increased in the summer period.

POC fluxes in traps at $30 \mathrm{~m}$ and $70 \mathrm{~m}$ at Sta. T1 ranged from 158 to $645 \mathrm{mg} \mathrm{C} . \mathrm{m}^{-2} \cdot \mathrm{d}^{-1}(337 \pm 153 \mathrm{mg}$ C.m $\left.\mathrm{m}^{-2} \cdot \mathrm{d}^{-1}\right)$ and from 95.2 to $811.5 \mathrm{mg} \mathrm{C} . \mathrm{m}^{-1} \cdot \mathrm{d}^{-1}$ $\left(294 \pm 183 \mathrm{mg} \mathrm{C} \cdot \mathrm{m}^{-2} \cdot \mathrm{d}^{-1}\right)$, respectively. The patterns of

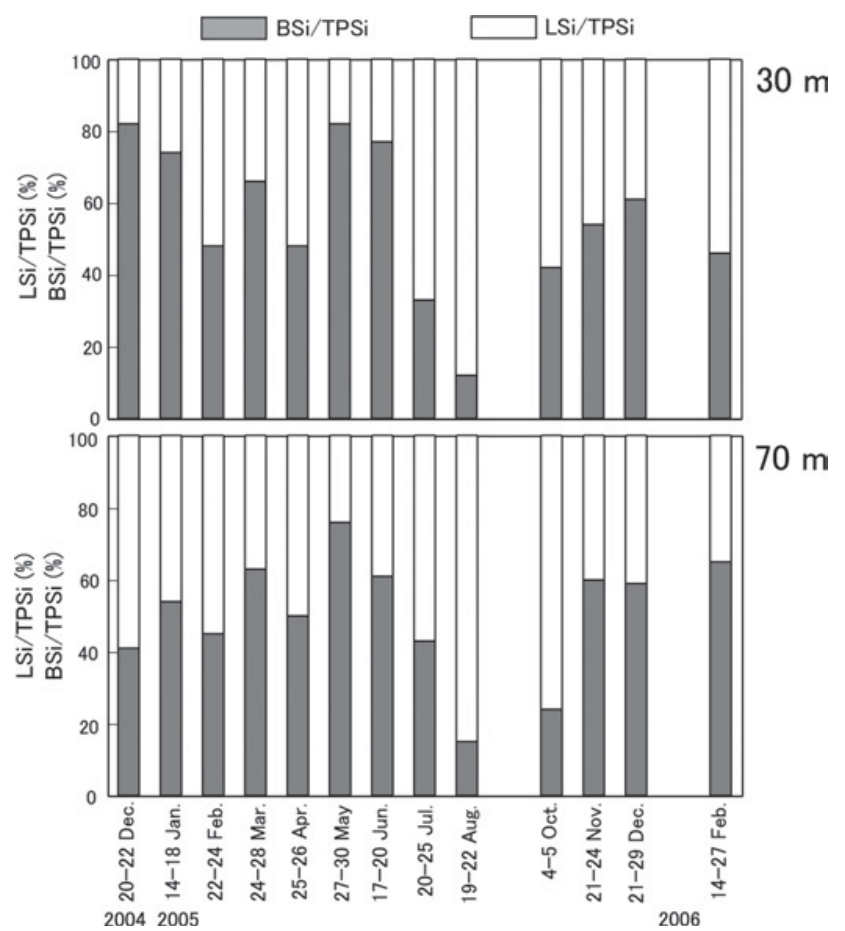

Fig. 7. Ratios of BSi and LSi fluxes to TPSi fluxes in the upper $(30 \mathrm{~m})$ and lower traps $(70 \mathrm{~m})$ at Station T1 in Lake Biwa from December 2004 to February 2006. 
Table 1. BSi fluxes estimated using sediment traps in freshwater Lakes.

\begin{tabular}{|c|c|c|c|c|}
\hline Site & $\begin{array}{l}\text { Lake surface and } \\
\text { maximum depth }\end{array}$ & Trap depth (m) & $\begin{array}{l}\text { BSi sediment trap fluxes } \\
\left(\mathrm{mg} \mathrm{Si} \cdot \mathrm{m}^{-2} \cdot \mathrm{d}^{-1}\right)\end{array}$ & Reference \\
\hline \multirow[t]{3}{*}{ Lake Malawi, East Africa } & $29600 \mathrm{~km}^{2}, 706 \mathrm{~m}$ & 100 & Annual mean 75.6 & (Bootsma et al., 2003) \\
\hline & & 140 & Annual mean 103.6 & \\
\hline & & 180 & Annual mean 137.2 & \\
\hline Lake Malawi, East Africa & $29600 \mathrm{~km}^{2}, 706 \mathrm{~m}$ & $300-350$ & $<94.7$ & (Pilskan, 2004) \\
\hline Trout Lake, Wisconsin USA & $2.68 \mathrm{~km}^{2}, 35.7 \mathrm{~m}$ & 25 & ca. $50-270$ & (Poister and Armstrong, 2003 \\
\hline Lake Lagano, Switzerland/Italy & $27.5 \mathrm{~km}^{2}, 288 \mathrm{~m}$ & 30 & Mean $99.2(20.8-620.6)$ & (Hofmann et al., 2002) \\
\hline Lake Michigan, USA & $58016 \mathrm{~km}^{2}, 281 \mathrm{~m}$ & 35 & Mean 166 & (Schelske et al., 1984) \\
\hline Lake Baikal, Russia & $31500 \mathrm{~km}^{2}, 1637 \mathrm{~m}$ & $200-255$ & Annual mean 174 & (Müller et al.. 2005) \\
\hline \multirow[t]{2}{*}{ Lake Biwa, Japan } & $670 \mathrm{~km}^{2}, 104 \mathrm{~m}$ & 30 & Mean $392(20-087)$ & This study \\
\hline & & 70 & Mean 313 (12-99) & \\
\hline
\end{tabular}

seasonal variation for PON fluxes (30 m: $37.5 \pm 14.4 \mathrm{mg}$ N.m $\left.{ }^{-2} \cdot \mathrm{d}^{-1}, 70 \mathrm{~m}: 31.7 \pm 18.2 \mathrm{mg} \mathrm{N} \cdot \mathrm{m}^{-2} \cdot \mathrm{d}^{-1}\right)$ and PP fluxes $\left(30 \mathrm{~m}: 3.90 \pm 2.12 \mathrm{mg}\right.$ P.m ${ }^{-2} \cdot \mathrm{d}^{-1}, 70 \mathrm{~m}: 3.68 \pm 2.25$ mg P.m $\left.{ }^{-2} \cdot \mathrm{d}^{-1}\right)$ were almost identical to those obtained for the POC flux.

The molar ratio of $\mathrm{BSi}$ to PP (BSi: PP) at depths of 30 and $70 \mathrm{~m}$ in trap material ranged from 11.1 to 185.6 $(100.8 \pm 62.1)$ and 10.6 to $232.7(88.1 \pm 74.1)$ throughout the observation period, respectively. The molar ratio of PON: PP in trap material at depths of 30 and $70 \mathrm{~m}$ ranged from 13.4 to $73.4(25.6 \pm 15.4)$ and from 10.7 to 48.9 $(21.1 \pm 9.4)$, respectively. The $\mathrm{BSi}$ : $\mathrm{PP}$ ratios in trap material were significantly higher than those in the water column throughout the observation period, while the PON: PP ratio in trap material were close to those in the water column.

Dominant algal groups in the sediment traps (30 and $70 \mathrm{~m}$ ) throughout the sampling period were diatoms (Asterionella, Aulacoseira, Fragilaria and Stephanodiscus) and chlorophytes (Closterium, Coelastrum and Staurastrum).

\section{Discussion}

\section{Seasonal variation in BSi fluxes}

In this study, BSi fluxes ranged from 20 to 1087 mg Si.m ${ }^{-2} \cdot d^{-1}(392 \pm 319)$ at $30 \mathrm{~m}$ and from 12 to 999 mg Si.m ${ }^{-2} \cdot d^{-1}(313 \pm 319)$ at $70 \mathrm{~m}$ in the northern basin of Lake Biwa (Fig. 6). These BSi fluxes are higher than those observed in other freshwater lakes of the world (Table 1). The annual basin-wide BSi flux in the northern basin of Lake Biwa was approximated using the annual BSi flux data collected from the $30 \mathrm{~m}$ trap (116 g Si. $\mathrm{m}^{-2} \cdot \mathrm{y}^{-1}$ ) and the total area of the lake areas deeper than $30 \mathrm{~m}$ in the northern basin $\left(393 \mathrm{~km}^{2}\right)$. Consequently, the basin-wide BSi flux becomes $4.6 \times 10^{7} \mathrm{~kg} \mathrm{Si.y}^{-1}$ $\left(1.6 \times 10^{9} \mathrm{~mol} \mathrm{Si.y}{ }^{-1}\right)$, which is equivalent to approximately twice the annual inflow from the rivers flowing into Lake Biwa $\left(2.5 \times 10^{7} \mathrm{~kg} \mathrm{Si} . \mathrm{y}^{-1}, 0.89 \times 10^{9} \mathrm{~mol} \mathrm{Si.y}^{-1}\right)$ (Goto et al., 2007). In the previous study, we reported that the sedimentation rate (which corresponded to permanent

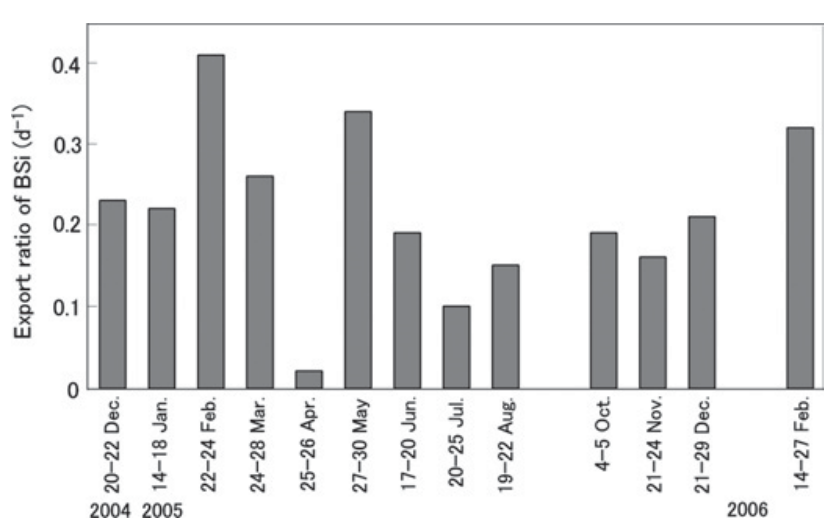

Fig. 8. Export ratio of BSi from the surface layer $(0-30 \mathrm{~m})$ in the northern basin of Lake Biwa from December 2004 to February 2006.

burial rate) of silica in Lake Biwa was $2.0 \times 10^{7} \mathrm{~kg} \mathrm{Si}^{-1}$ (Goto et al., 2007). These results mean that a significant proportion of $\mathrm{BSi}$ that settled on the lake bottom is decomposed quickly and then the regenerated DSi is reutilized by diatoms. These findings indicate that an internal cycling of silica occurs intensively in Lake Biwa.

BSi fluxes in both of the traps in the northern basin of Lake Biwa showed a tendency to increase during winter period (Fig. 6); the ratio of winter BSi flux to annual BSi flux was 53\% (December 2004 to February 2005) and 52\% (December 2005 to February 2006) in the $30 \mathrm{~m}$ trap, and 27\% (December 2004 to February 2005) and $62 \%$ (December 2005 to February 2006) at $70 \mathrm{~m}$ trap, respectively. In addition, the BSi flux: TPSi flux ratios at both traps, particularly the $30 \mathrm{~m}$ trap, were high throughout the winter period (Fig. 7). Azumi et al. (2009) reported that the rate of DSi regeneration from sediments in the hypolimnion (water depth $>30 \mathrm{~m}$ ) of Lake Biwa is almost constant throughout the year because the water temperature in the hypolimnion of Lake Biwa does not vary markedly throughout the year $\left(8.3 \pm 1.0^{\circ} \mathrm{C}\right)$. The findings of this study indicate that the silica pump in Lake Biwa is particularly efficient during winter, with the size of the silica sink increasing during the circulation period (Goto et al., 2007). 


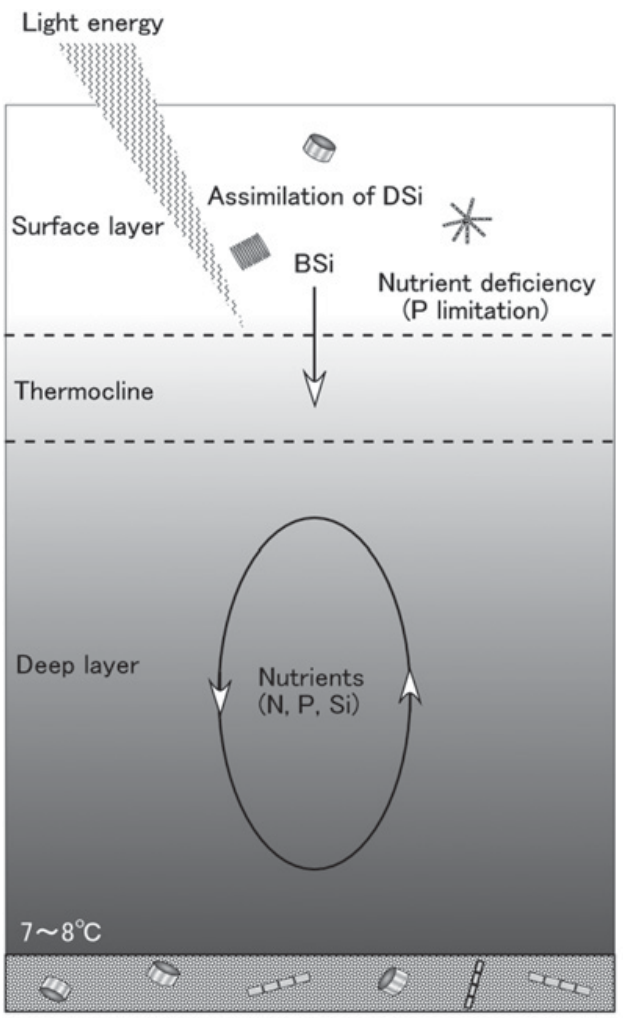

Stratification period

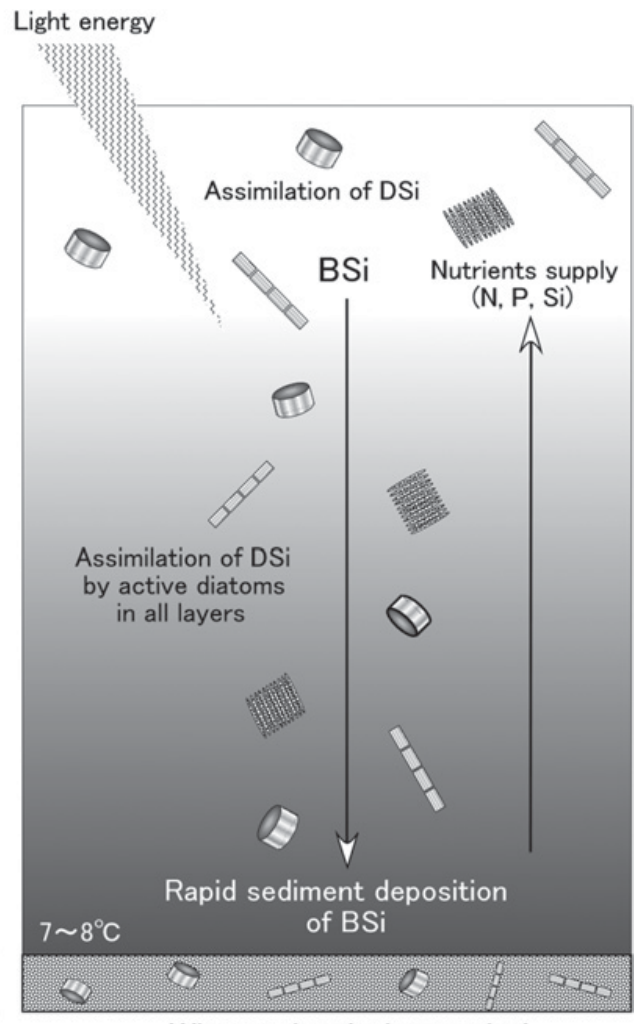

Winter circulation period

Fig. 9. Conceptual diagrams of Si dynamics in the periods of stratification and winter circulation in Lake Biwa.

In order to explain that the largest sediment flux of BSi occurs during winter, BSi production rate in Lake Biwa was roughly estimated as follows:

$\mathrm{BSi}$ production rate $\left(\mathrm{mg}\right.$ Si. $\left.\mathrm{m}^{-2} \cdot \mathrm{d}^{-1}\right)=$ primary production rate $\left(\mathrm{mg} \mathrm{C} \cdot \mathrm{m}^{-2} \cdot \mathrm{d}^{-1}\right) \times \mathrm{Si} / \mathrm{C}$ ratio,

where primary production rate is $385 \mathrm{mg} \mathrm{C} . \mathrm{m}^{-2} \cdot \mathrm{d}^{-1}$ (unpublished date: mean value from December 2006 to February 2007 at Sta. T1), assuming that all primary production was carried out by diatoms. $\mathrm{Si} / \mathrm{C}$ weight ratio is 1.84 (molar ratio: 0.79) from 12 freshwater species collected from natural waters (Sicko-Goad et al., 1984). As a result, BSi production rate becomes $708 \mathrm{mg} \mathrm{Si.m}{ }^{-2} \cdot \mathrm{d}^{-1}$ and this estimate can account nearly for the BSi flux during winter. Saxton et al. (2012) reported that $\mathrm{Si} / \mathrm{C}$ fixation ratios of diatoms in Lake Erie were significantly higher in winter and thus this diatom-dominated winter community disposed to higher sinking rates.

\section{Silica sink characteristics during winter circulation period}

In this study, export ratio from the surface layer can be estimated by the quotient (BSi flux at $30 \mathrm{~m}$ trap: $\mathrm{mg}$ Si. $\left.\mathrm{m}^{-2} \cdot \mathrm{d}^{-1}\right) /($ standing stock of BSi in water column of 0-30 m depth: mg Si.m ${ }^{-2}$ ). Except for May 2005, there were two peaks in the export ratio during the circulation period (February 2005 and 2006) (Fig. 8). During this period of low water temperature, centric diatoms, such as
Aulacoseira, Fragilaria and Stephanodiscus, become dominant in Lake Biwa (Kawabata, 1987; Goto et al., 2008). In addition, we also observed that dominant algal groups in the sediment traps at 30 and $70 \mathrm{~m}$ were diatoms (Asterionella, Aulacoseira, Fragilaria and Stephanodiscus) during the circulation period. These high specific-gravity diatoms sink rapidly to the bottom of Lake Biwa in the event of a disruption in the thermocline, i.e. a marked transfer of diatoms to the deep layer occurs by vertical convection (density current) in the circulation period. More than $97 \%$ of diatom frustules (cell numbers) that accumulate in the surface sediment layer (0-6 m) of northern basin of Lake Biwa are comprised of two groups of centric diatoms, Aulacoseira spp. and Stephanodiscus spp. (Negoro, 1960, 1967). Similarly, we observed large quantities of frustules from these two groups of diatom genera in the sediments of the lake bottom. It therefore appears that BSi flux in Lake Biwa increases during the winter period when DSi and other nutrients move from the hypolimnion to the epilimnion, because these relatively heavy diatoms settle quickly in the hypolimnion where the water temperature is lower $\left(7-8^{\circ} \mathrm{C}\right)$ before undergoing biological and physicochemical degradation in the epilimnion (Horne and Goldman, 1994; Ryves et al., 2003).

In the past decade, there have been several reports stressing the importance of inputs of BSi derived from terrestrial plants (phytoliths) (Conley, 2002; Bootsma et al., 2003). Phytoliths may affect the silica cycle in Lake Biwa, because approximately $70 \%$ of the catchment basin 
$\left(3174 \mathrm{~km}^{2}\right)$ of Lake Biwa is forest area. However, in this study, pelagic diatom frustules (including some benthic diatoms in the littoral zone) were overwhelmingly observed in trap and sediment samples, therefore it is assumed that phytoliths contribute little to $\mathrm{BSi}$ flux in Lake Biwa.

Although the growth of phytoplankton in Lake Biwa is generally limited by phosphorus, this limitation is alleviated during the winter period by an increase in nutrient supply from deeper layers, resulting in potential photosynthetic competence of phytoplankton tending to increase at this time of year (Tezuka, 1984; Goto et al., 2008). Similarly, in this study, relatively high $F_{\mathrm{v}} / F_{\mathrm{m}}$ values of phytoplankton were distributed approximately uniformly in all layers during the mixing period (Fig. 5B). In addition, Chl $a$ concentrations in all layers at this time were also approximately uniform (Fig. 5A). Taken together, these results indicate that active diatoms also sink rapidly into the hypolimnion and that metabolically active diatoms are observed in all water layers during winter. This finding is supported by the fact that the molar ratios of $\mathrm{BSi}$ to $\mathrm{PP}$ in the water column at 30 and $70 \mathrm{~m}$ were almost equal during the circulation period in February 2005 and 2006 (Fig. 4). Silicon metabolism and photosynthesis are not directly coupled in diatoms, and DSi uptake by diatoms increases slightly in the dark (Ragueneau et al., 2000; Wetzel, 2001). Indeed, it may be presumed that diatoms in a wider layer containing a part of aphotic zone take up DSi in the circulation period, which means that this DSi uptake and subsequent silicification processes occur in a wider layer.

It can therefore be concluded that BSi flux in Lake Biwa is very high compared to other lakes around the world and that this flux increases markedly during the winter period. Consequently, the ratio of BSi flux in winter period to annual BSi flux ranges between 27 and $62 \%$. The reason for increase in the size of the silica sink during winter period is outlined in Figure 9. Briefly, increase in nutrient supply from the deeper layers to the surface layers during the winter period contributed to the growth and multiplication of diatoms in the surface layer. Shortly thereafter, active diatoms were distributed almost uniformly in all layers by the action of vertical convection and/or sedimentation of diatoms. These diatoms transform the DSi into BSi in a wider layer containing a part of aphotic layer and their rigid and heavy frustules accumulate rapidly in bottom sediments where they are less susceptible to dissolution due to low water temperatures in the hypolimnion $\left(7-8^{\circ} \mathrm{C}\right)$ throughout the year. Lake Biwa in Japan is thus a very large silica sink because of the phenomena associated with the winter period described above.

Acknowledgements. We are grateful to Captain Bun-ichiro Kaigai of RV Hassaka, the University of Shiga Prefecture, for his generous assistance during sample collection. Thanks are also due to the staff of the Limnological Laboratory, USP, for their contributions to water sampling and chemical analysis.

\section{References}

Azumi H., Goto N. and Mitamura O., 2009. Regeneration of silicic acid from sediment in Lake Biwa, Japan. Verh. Int. Verein. Limnol., 30, 1041-1045.

Bendschneider K. and Robinson R.J., 1952. A new spectrophotometric method for the determination of nitrite in sea water. J. Mar. Res., 11, 87-96.

Billen G., Lancelot C. and Meybeck M., 1991. N, P, and Si retention along the aquatic continuum from land to ocean. In: Matoura R.F.C., Martin J.M. and Wollast R. (eds.), Ocean Margin Processes in Global Change, Wiley and Sons, Chichester, 19-44.

Bootsma H.A., Hecky R.E., Johnson T.C., Kling H.J. and Mwita J., 2003. Inputs, outputs, and internal cycling of silica in a large, tropical lake. J. Great. Lakes. Res., 29, 121-138.

Conley D.J., 2002. Terrestrial ecosystems and the global biogeochemical silica cycle. Global Biogeochem. Cy., 16, 68-1-68-8.

Conley D.J., Schelske C.L. and Stoermer E.F., 1993. Modification of the biogeochemical cycle of silica with eutrophication. Mar. Ecol. Progr. Ser., 101, 179-192.

DeMaster D.J., 1981. The supply and accumulation of silica in the marine environment. Geochim. Cosmochim. Acta, 45, $1715-1732$.

Fujinaga T. and Hori T., 1982. Analytical methods of lake water. In: Environmental Chemistry on Lake Biwa, Japan Society for the Promotion and Science, Tokyo, 113-131 (in Japanese).

Garnier J., Beusen A., Thieu V., Billen G. and Bouwman L., 2010. N:P:Si nutrient export ratios and ecological consequences in coastal seas evaluated by the ICEP approach. Global Biogeochem. Cy., 24, BG0A05.

Gong G.C., Chang J., Chiang K.P., Hsiung T.M., Hung C.C., Duan S.W. and Codispoti L.A., 2006. Reduction of primary production and changing of nutrient ratio in the East China Sea: effect of the three Gorges dam? Geophys. Res. Lett., 33, L07610.

Goto N., Iwata T., Akatsuka T., Ishikawa M., Kihira M., Azumi H., Anbutsu K. and Mitamura O., 2007. Environmental factors which influence the sink of silica in the limnetic system of the large monomictic Lake Biwa and its watershed in Japan. Biogeochemistry, 84, 285-295.

Goto N., Kihira M. and Ishida N., 2008. Seasonal distribution of photosynthetically active phytoplankton using pulse amplitude modulated (PAM) fluorometry in the large monomictic Lake Biwa, Japan. J. Plankton. Res., 30, 1169-1177.

Hofmann A., Roussy D. and Filella M., 2002. Dissolved silica budget in the North basin of Lake Lugano. Chem. Geol., 182, $35-55$.

Holm-Hansen O., Lorenzen C.J., Holmes R.W. and Strickland J.D.H., 1965. Fluorometric determination of chlorophyll. J. Cons. Cons. Int. Explor. Mer., 30, 3-15.

Homborg C., Pastuszak M., Aigars J., Siegmund H., Mörth C.-M. and Ittekkot V., 2006. Decreased silica land-sea fluxes through damming in the Baltic Sea catchment - Significance of particle trapping and hydrological alterations. Biogeochemistry, 77, 265-281.

Hori T., Itasaka O. and Mitamura O., 1969. The removal of dissolved silica from freshwater in the Lake Biwa-ko. Mem. 
Fac. Liberal Arts Educ. Shiga Univ., 19, 45-51 (in Japanese with English summary).

Horne A.J. and Goldman C.R., 1994. Phytoplankton and periphyton. In: Limnology, 2nd edn, McGraw-Hill, New York, 226-264.

Humborg C., Ittekkot V., Cociasu A. and Bodungen B., 1997. Effect of Danube River dam on Black Sea biogeochemistry and ecosystem structure. Nature, 386, 385-388.

Humborg C., Conley D.J., Rahm L., Wulff F., Cociasu A. and Ittekkot V., 2000. Silicon retention in river basins: far-reaching effects on biogeochemistry and aquatic food webs in coastal marine environments. Ambio, 29, 45-50.

Kawabata K., 1987. Ecology of large phytoplankton in Lake Biwa: population dynamics and food relations with zooplankters. Bull. Plankton Soc. Japan, 34, 165-172.

Kawamura S. and Goto K., 1994. Silicate. In: The Japan Society for Analytical Chemistry, Hokkaido Branch (ed.), Mizu no bunseki, 4th edn, Kagakudojin, Kyoto, 181-184 (in Japanese).

Menzel D.W. and Corwin N., 1965. The measurement of total phosphorus in seawater based on the liberation of organically bound fraction by persulfate oxidation. Limnol. Oceanogr., 10, 280-282.

Miyajima T., Nakano S. and Nakanishi M., 1995. Planktonic diatoms in pelagic silicate cycle in Lake Biwa. Jpn J. Limnol., 56, 211-220.

Müller B., Maerki M., Schmid M., Vologina E.G., Wehrli B., Wüest A. and Sturm M., 2005. Internal carbon and nutrient cycling in Lake Baikal: sedimentation, upwelling, and early diagenesis. Global Planet. Change, 46, 101-124.

Mullin J.B. and Riley J.P., 1955. The colorimetric determination of silicate with special reference to sea and natural waters. Anal. Chim. Acta, 12, 162-176.

Murphy J. and Riley J.P., 1962. A modified single solution method for the determination of phosphate in natural waters. Anal. Chim. Acta, 27, 31-36.

Negoro K., 1960. Studies on the diatom-vegetation of Lake Biwa-ko. Jpn J. Limnol., 21, 200-220 (in Japanese).

Negoro K., 1967. An analytical study of diatom shells in the bottom deposits of Lake Biwa-ko, based on a new core-sample. Jpn J. Limnol., 28, 132-135 (in Japanese).

Nixon S.W., 2003. Replacing the Nile: are anthropogenic nutrients providing the fertility once brought to the mediterranean by a great river? Ambio, 32, 30-39.

Pilskaln C.H., 2004. Seasonal and interannual particle export in an African rift valley lake: a 5-yr record from Lake Malawi, southern East Africa. Limnol. Oceanogr., 49, 964-977.

Poister D. and Armstrong D.E., 2003. Seasonal sedimentation trends in a mesotrophic lake: influence of diatoms and implications for phosphorus dynamics. Biogeochemistry, 65, $1-13$.

Ragueneau O., Tréguer P., Leynaert A., Anderson R.F., Brzezinski M.A., DeMaster D.J., Dugdale R.C., Dymond
J., Fischer G., François R., Heinze C., Maier-Reimer E., Martin-Jézéquel V., Nelson D.M. and Quéguiner B., 2000. A review of the $\mathrm{Si}$ cycle in the modern ocean: recent progress and missing gaps in the application of biogenic opal as a paleoproductivity proxy. Global Planet. Change, 26, 317-365.

Ryves D.B., Jewson D.H., Sturm M., Battarbee R.W., Flower R.J., Mackay A.W. and Granin N.G., 2003. Quantitative and qualitative relationships between planktonic diatom communities and diatom assemblages in sedimenting material and surface sediments in Lake Bikal, Siberia. Limnol. Oceanogr., 48, 1643-1661.

Sagi T., 1966. Determination of ammonia in sea water by the indophenol method and its application to the coastal and off-shore waters. Oceanograph. Mag., 18, 43-51.

Saxton M.A., D'souza N.A., Bourbonniere R.A., McKay R.M.L. and Wilhelm S.W., 2012. Seasonal Si:C ratios in Lake Erie diatoms - evidence of an active winter diatom community. J. Great Lakes Res., 38, 206-211.

Schelske C.L. and Stoermer E.F., 1971. Eutrophication, silica depletion, and predicted changes in algal quality in Lake Michigan. Science, 173, 423-424.

Schelske C.L. and Stoermer E.F., 1972. Phosphorus, silica and eutrophication in Lake Michigan. In: Likens G.E. (ed.), Nutrients and Eutrophication. American Society of Limnology and Oceanography, Kansas, 157-171.

Schelske C.L., Eadie B.J. and Krausse G.I., 1984. Measured and predicted fluxes of biogenic silica in Lake Michigan. Limnol. Oceanogr., 29, 99-110.

Schreiber U., Hormann H., Neubauer C. and Klughammer C., 1995. Assessment of photosystem II photochemical quantum yield by chlorophyll fluorescence quenching analysis. Aust. J. Plant. Physiol., 22, 209-220.

Sferratore A., Billen G., Garnier J., Smedberg E., Humborg C. and Rahm L., 2008. Modelling nutrient fluxes from subarctic basins: comparison of pristine vs. dammed rivers. J. Mar. Syst., 73, 236-249.

Sicko-Goad L.M., Schelske C.L. and Stoermer E.F., 1984. Estimation of intracellular carbon and silica content of diatoms from natural assemblages using morphometric techniques. Limonol. Oceanogr., 29, 1170-1178.

Teubner K. and Dokulil M.T., 2002. Ecological stoichiometry of TN: TP: SRSi in freshwaters: nutrient ratios and seasonal shifts in phytoplankton assemblages. Arch. Hydrobiol., 154, 625-646.

Tezuka Y., 1984. Seasonal variations of dominant phytoplankton, chlorophyll a and nutrient levels in the pelagic regions of Lake Biwa. Jap. J. Limnol., 45, 26-37.

Turner R.E., Rabalais N.N., Justic D. and Dortch Q., 2003. Global patterns of dissolved N, P and $\mathrm{Si}$ in large Rivers. Biogeochemistry, 64, 297-317.

Wetzel R.G., 2001. Iron, sulfur, and silica cycles. In: LimnologyLake and River Ecosystems--, Academic Press, San Diego, 289-330. 